\title{
Self-concept as a Factor in Academic Achievement
}

\author{
Areopagita Yésyka Bustillos Gómez \\ PhD Student, Autonomous University Chapingo
}

\begin{abstract}
This research presents a description of the results of the Piers-Harris Self-concept Assessment Scale (1984), applied anonymously among 300 students at a Technical Junior High School in Mexico City, for comparing with academic achievement or grade averages. To interpret the results, the questionnaires were grouped according to similar grade averages and total scores on the scale. As a result we got four sets of questionnaires, or four possible forms of perceiving academic self-concept related with grade averages. In agreement with the interpretation of the subtotal scores and items, generally talking it is possible to express that the need of social interaction; the obedience to hierarchical figures as the teacher; the vision that luckiness is related with learning; and a probable sense of helplessness or futility; mixed with political, economic, and social circumstances have influenced the attitude of Mexicans toward learning and their perceptions of academic self-concept.
\end{abstract}

Keywords: Academic self-concept, average grades

\section{Introduction}

Some Mexico City students in mandatory junior high school who are rejected by their peers or have poor grades do not appear to be concerned with school or the approval by their teachers. This study observes these carefree students whose life aspirations are totally disconnected from any educational institution. Failure to pass their subjects or even obtain their junior high or high school diploma does not appear to affect their academic self-concept or images of themselves based on their academic performance and the academic skills that determine it (González, 2005).

So if students are unconcerned about their grades or the school they attend, what is the relationship between academic self-concept and grade average?

\section{Background}

Self-concept has been a well-researched topic in secondary and university students given the important role it plays in academic performance. As González-Pineda \& Núñez (1993) point out, the results found by the work carried out in the last three decades on the relationship between self-concept and academic performance lead to a differentiation of four possible patterns or models of causality between self-concept and academic performance.

Pattern 1. Grade average determines self-concept, experiences of academic success or failure significantly affect student self-respect and self-image, which could be explained by the role of evaluations of significant others (Rosenberg, 1979) or the theory of social comparison (Rogers, Smith and Coleman, 1978; Marsh, 1987, 1990; Marsh and Parker, 1984).

Pattern 2. The levels of self-concept determine the degree of academic achievement, a point of view maintained by selfconsistency theory (Jones 1973) and self-respect theory formulated by Covington (1984). 
Pattern 3. Self-concept and academic achievement are mutually influencing and determining. Marsh (1984) proposes a model of reciprocal relationships between self-concepts, attributions, and performance, with the particularity that a change in any of them produces changes in the others in order to restore initial balance.

Pattern 4. It is possible that outside variables are the cause of both self-concept and performance, as Maruyama, Rubin, \& Kinsburg (1981) propose.

We can infer that in the relationship between of academic self-concept and school performance, self-concept in some studies influenced school performance, while in others it was the reverse; in still other investigations the relationship was reciprocal or unrelated.

According with these findings, most quantitative studies have not looked into the contexts which surrounds the relationship between academic self-concept and academic achievement. A case study is necessary that takes into account historical, social, political, and community circumstances on the perception and relationship between academic self-concept and grade averages.

This descriptive study aims to describe the relationship of academic self-concept and academic achievement in its natural context of Technical Junior High School 66 in the Cuchilla-Pantitlan neighborhood on the east side of Mexico City. Variables were the student's academic self-concept understood as the student's own conceptualization of his- or herself in the academic field, and the average grade in all subjects, (understood as their academic achievement per ANUIES, 2002). The subjects were 300 students of 11 to 13 years of age.

The technique used for this research was the survey. The instrument for the anonymous survey was the adapted and standardized Piers-Harris Self-Assessment Scale for adolescents (Piers 1984). The Piers instrument is grouped into six subscales that assessed behavior, academic achievement or intellectual status, appearance and physical attributes, anxiety, popularity, happiness, and satisfaction as perceived by the adolescent.

\section{Results and Discussion}

The first range or grouping of questionnaires was separated by virtue having scores of 350-320 total points in the instrument with grade averages of 9 and 10 . Another group of schoolchildren had 330-300 total points on the instrument, with grade averages of 6 and 7 . This created the total four ranges of grouping or organization of the questionnaires by internal similarities of each grouping, as detailed in Table 1.

Table 1. Ranges of data

\begin{tabular}{|l|l|l|l|}
\hline & $\begin{array}{l}\text { Total score in Piers-Harris Self- } \\
\text { Assessment Scale }\end{array}$ & $\begin{array}{l}\text { Grade average from elementary } \\
\text { school and achievement in junior high }\end{array}$ & Number of questionnaires \\
\hline 1 & $350-320$ & 9 and 10 & 152 \\
\hline 2 & $330-300$ & 6,7, and 8 & 101 \\
\hline 3 & $260-230$ & 8 and 9 & 20 \\
\hline 4 & $225-215$ & 6 and 7 & 27 \\
\hline
\end{tabular}

Averages or means of the partial scores of the questionnaires were obtained for subscales of each range or grouping of questionnaires. The results have been described from highest to lowest score for the average in each subscale in each academic achievement range with similar total score on the questionnaire, and then from highest to lowest average score for the same subscale in each of the four ranges. The analysis of results arises from comparing of averages of the questions by subscales by average grades according to Piers the signification, of the relation to the theoretical framework, the authors, the context, and the Mexican community. Afterward a brief conclusion of each range is detailed in the same order.

Average grades for ninety percent of teens dropped in the transition from elementary school to junior high. It is considered a high score in the Piers scale because it shows about $80 \%$ of the total score, and at the same time is considered a low score because it accounts for about $50 \%$ of the total score. 
Table 2. Relationship between the two variables: grade average with self-concept score

\begin{tabular}{|c|c|c|c|c|}
\hline $\begin{array}{l}\text { Average academic } \\
\text { achievement }\end{array}$ & $\begin{array}{l}8,9,10 \\
\text { high }\end{array}$ & $\begin{array}{l}6,7 \\
\text { low }\end{array}$ & $\begin{array}{l}8,9 \\
\text { average }\end{array}$ & $\begin{array}{l}6,7 \\
\text { low }\end{array}$ \\
\hline Number of students & 152 & 101 & 20 & 27 \\
\hline $\begin{array}{l}\text { Percentage of total } \\
\text { surveys }\end{array}$ & 50 & 35 & 6 & 9 \\
\hline $\begin{array}{l}\text { Total score in Self- } \\
\text { concept }\end{array}$ & $\begin{array}{l}350-320 \\
\text { high }\end{array}$ & $\begin{array}{l}330-300 \\
\text { alto }\end{array}$ & $\begin{array}{l}260-230 \\
\text { average }\end{array}$ & $\begin{array}{l}225-215 \\
\text { low }\end{array}$ \\
\hline $\begin{array}{l}\text { Subscale } 1 \text { behavior } \\
\text { responsibility: } 75 \text { total } \\
\text { points }\end{array}$ & average: 69.3 & average: 45.3 & average: 47.4 & average: 28.7 \\
\hline $\begin{array}{l}\text { Subscale } 2 \\
\text { achievement academic } \\
\text { feeling: } 75 \text { total points }\end{array}$ & average: 64.3 & average: 53.3 & average: 48.4 & average: 36.6 \\
\hline $\begin{array}{l}\text { Subscale } 3 \text { Attitude } \\
\text { physical leadership: } 60 \\
\text { total points }\end{array}$ & average: 56.2 & average: 58.3 & average: 44.2 & average: 34.2 \\
\hline $\begin{array}{l}\text { Subscale } 4 \\
\text { Nervousness: } 65 \text { total } \\
\text { points }\end{array}$ & average: 58.5 & average: 54.4 & average: 50.7 & average: 45.6 \\
\hline $\begin{array}{l}\text { Subscale } 5 \text { Popularity: } \\
55 \text { total points }\end{array}$ & average: 43.3 & average: 54.6 & average: 27.8 & average: 29.3 \\
\hline $\begin{array}{l}\text { Happiness : } 55 \text { total } \\
\text { points satisfaction }\end{array}$ & average: 54.1 & average: 54.8 & average: 40.6 & average: 31.5 \\
\hline
\end{tabular}

Results from highest to lowest average score of subscales of the same range

\section{First range}

A total of 152 students had high scores on Piers's overall scale of self-concept (approximately 350 to 320 total points), with high grades in all subjects in the third grading period, as well as from primary school (averages of 9 to 10 on their transcripts).

We can say that the first range are active students who are in the process of becoming autonomous and have an internal locus of control. The behavior subscale of this first range had the highest average of the total sample, 69.3 average. These students, with high academic achievement and high scores on the scale of self-concept, may have achievement based on a perception of personal competence and goals directed toward the realization and mastery of a given task. High motivation positively affects their academic behavior because they acquire an elevated academic status reflected not necessarily in greater knowledge and skills, but more than anything else in grades, which is almost always the most important aim for students of the first range.

On many occasions, due to the tendency of traditionalist learning, the student with good grades understands that a large part of getting good grades resides in proper classroom behavior, which means being quiet, attentive, and obedient to the teacher. Thus, the filial character and obedience in the adolescent which takes root over time and necessitates the presence of authority for learning (Díaz Loving, 1982), in contrast to Argentine adolescents, for example, who esteem being smart and cultured rather than getting good grades.

Adolescents therefore do not generally find sense in many activities, yet their high sense of obedience and responsibility guide them to accomplish all their activities to achieve their priority: high grades. These students with high grades have developed a sense of altruism toward school and demonstrate good behavior that have a positive impact their academic achievement.

The second highest score in this first range was in the subscale of academic achievement, with an average of 64.3 . In this regard, Piers states that the self-concept is not innate in the manner it arises, develops, and organizes, but rather it is built 
and defined throughout development due to the influence of significant persons in the family, school, and social environments, in interaction with their own experiences of success and failure.

Thus when the students in this first range are trying to solve some school task or to comprehend some new learning, the social environment, particularly that of the family, plays a central role in the evaluative process that underlies their selfconcept.

Piers (1984), also states that the self-concept fulfills a mediating function that facilitates or prevents the person from performing a task (in accordance with their self-assessment), i.e., conditions and feeds back the behavior in the same way as parents and teachers say they are encouraging these students and these learners are, in turn, represent a positive feedback to progress. As James (1890) put it, our self-concept is in proportion to what we desire to be, and what we are or feel we can become.

Through the comparison of the responses in this subscale for the first range, we can say that these students usually identify difficulties or obstacles in learning or schoolwork and feel the confidence or need to continue trying until they achieve the assigned task or learning.

Similarly, Creoles in the colonial times of New Spain knew of their intellectual performance because they received education and felt independence as power and autonomy for the purpose of using their knowledge to advance; these individuals therefore perceived their locus of internal control (Rotter, 1966).

The grades of these students in the first range seem to be generally synonymous with intelligence-academic status, something common in Mexico City where most adolescent students have no activity outside school. This is a situation opposite to the Argentine case where the status is socially granted for being cultured, intelligent, and within the stage of adolescence for being thoughtful, critical, and creative. Therefore returning with adolescents of the first range, success or failure in school is related to central aspects of their self-assessment and, in turn, this academic self-assessment influences their successes which ripple out to all aspects of her life, since school and family are the two most significant, or at times sole, contexts.

The lowest score in this first range was in the subscale of popularity where an average of 43.3 was obtained out of a 55 total points. The responses from these subjects indicated that popularity is not perceived as among their priorities, but the consequence of their qualifications and good academic achievement usually become suitable friends for the rest of the class.

Feelings of academic efficiency - central components of self-concept - motivate them to organize study activities and the use of learning strategies, which leads this type of adolescent to be natural leaders, with the consequence that they give less importance to popularity.

They are adolescents who are often sought out by the rest of the group and supported as leaders in various activities due to their academic and personal efficacy. In some cases these teens desire like less popularity than they already enjoy.

With regard to popularity in junior high school, in many cases having prestige as a student does not imply being cultured or very intelligent for broad, rapid comprehension diverse types of knowledge, but rather on obtaining good grades.

This is also congruent with Valdez's studies where, compared to Argentine adolescents, for most Mexican students it is more important to obtain good grades than to be intelligent or cultured (Valdez Medina, 2005). This often leads Mexican students to be filial and feel happy in groups of schoolmates because of good grades. In some cases these persons are followed by their companions because of their high averages since excellent qualifications are sometimes synonymous with being intelligent. It is important to note that it is not that these students with high scores on the Piers scale and excellent grades are very socially skilled - they are also sometimes shy — but generally are very convenient classmates to have and are followed by the rest of their classmates. 
Graphic 1: Six subscales in the first range

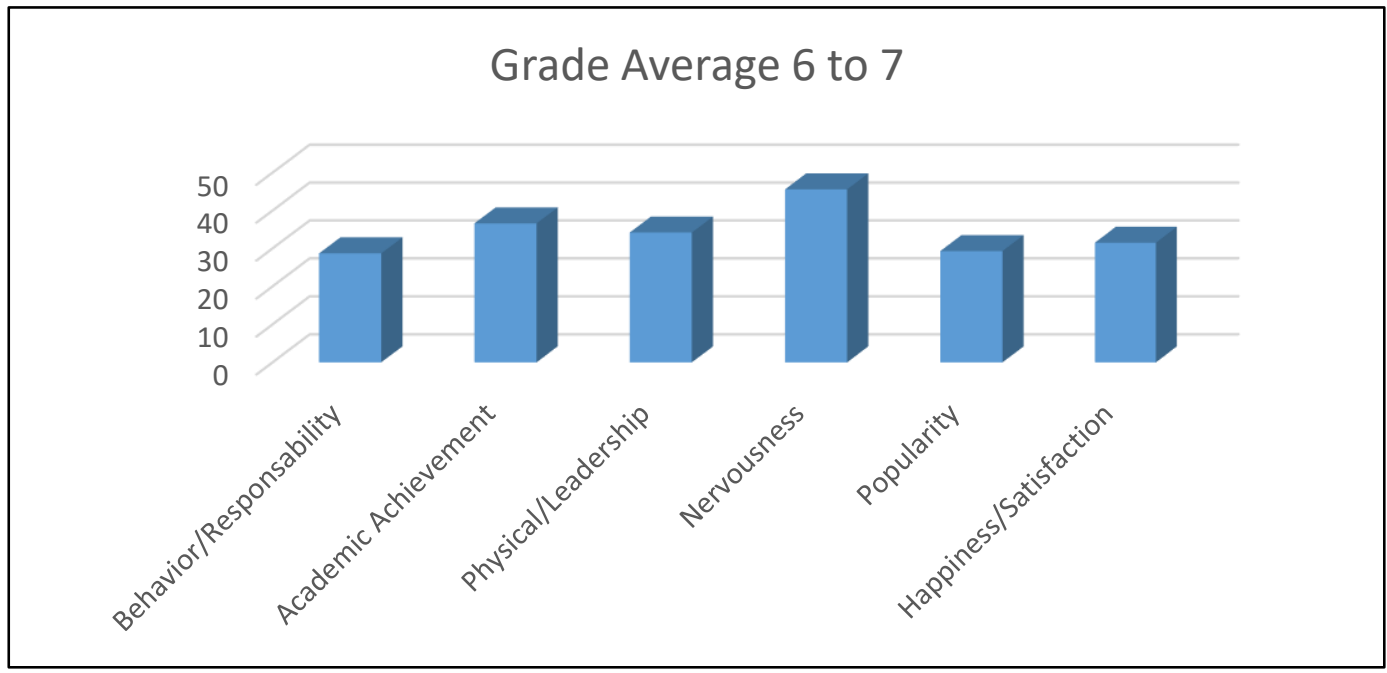

Second range

Respondents to 101 questionnaires reported high scores overall for self-concept (approximately 300-330 total points), and with low academic achievement in the third grading period and in primary school (an averages of 6 and 7 ). The highest score in the leadership subscale was an average of 58.3 in this second range.

Their highest scores were in leadership, popularity, and satisfaction because of what these subscales of Piers' instrument evaluate, it may be affirmed that they are adolescent leaders with positive feelings toward school. The scores on the subscales indicate these adolescents do not generally feel useful, nor motivated to study junior high school although they have a positive self-concept. ACADEMIC knowledge or grades are not useful to these adolescents, but rather obedience and belonging to a social group in their community.

The highest scores these students had their on the leadership subscale was nearly 60 points, which places them as skillful and socially entertaining students. Because of their need for belonging to the school group, these students often interrupt class with comments that identify them as fun, carefree, and astute.

This may also be due to the fact that, in Mexico City the lack of credibility in certain authorities, the certainty of competitiveness, mastery of skills or knowledge are not the only mechanisms to social advancement, which is why some students explain their expectations for future accomplishments on the basis of their social relationships, luck, chance, or affiliation.

These students of low academic achievement and high scores on the self-concept scale generally have relatives who are in sales, underemployed, or in the United States and under their influence have their expectations placed in commerce, a position, or migration. This is why the study of this junior high school is not an attractive or useful option for them. This above is confirmed by the sense of filiation, which Diaz-Loving refers to, because membership in the family-social group guides these adolescents to focus their aspirations on being recognized in such environments.

According to Santos (2010) individuals believes would appear numbered in each person by the multiform concourse of his or her particular circumstances. Like some indigenous and mestizo people as well as contemporary students perceive their realities to be unique because they have not experienced and lived in other contexts with distinct circumstances, realities, and needs. When this is transferred to the school environment, it would appear that a unique academic reality exists for 
Mexican adolescents in the second range where progress via study, or where knowledge as the basic skills for life development, are not in their control but rather in the control of government, climate, religion, etc., make it useless to strive for something that offers no profit or utility in daily and future life.

The second and third highest average scores within this second range were for the subscales of happiness and popularity, with 54.8 and 54.6 points respectively. Because the interaction between the individual and his or her culture-community has the force of an axiom (Diaz-Guerrero, 1979), the previous scores show an interrelation between the popularity of their school or community and the happiness perceived by these adolescents with low academic achievement.

The communities of these students tend to be considered high risk for their crime rates. Insofar as these students' personality characteristics, some are very talkative or extroverted, and in their community-neighborhoods the most socially valued people are fun, cheerful, carefree, and engaged in commerce (possibly licit or not), so that study is not very common nor socially very esteemed. The average for anxiety was the third highest average with 54.4 points in this second range. The lowest score within this second range was in the behavior-responsibility subscale with only 45.3 points. They are students who in effective concordance with the Piers questionnaire; they can be counted on for any physical or extracurricular activity such as dance and civic ceremonies. They are the life of the group and the most difficult for the teacher to discipline.

Graphic 2: Subscales in the second range

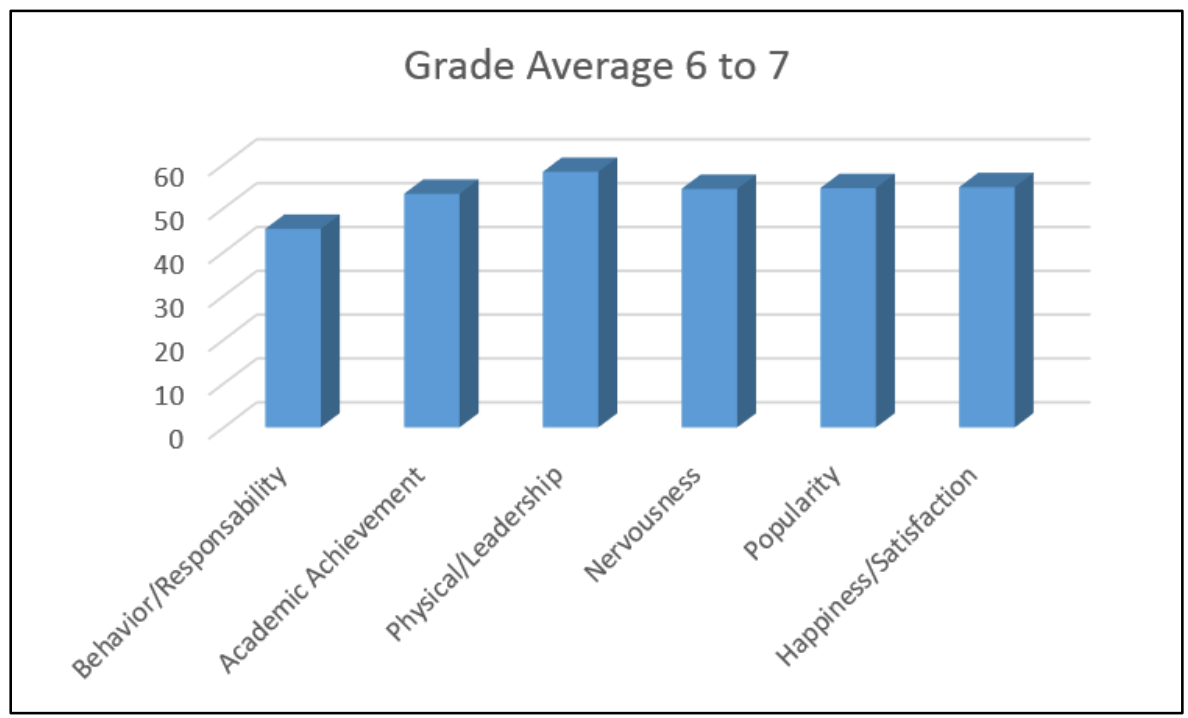

\section{Third Range}

There were 20 respondents with low scores (260-230) on the global self-concept scale and with grade averages for all subjects in the third "bimester" ( a period of two months in Mexico for evaluating in basic schools) and elementary school (averages between 7 and 8). The highest average was in the subscale for anxiety with 50.7 points. This is probably due to the strong the sense of obedience as a duty, which is implicit in the sense of religiosity and the sense of vulnerability since the period of the Spanish Conquest.

It may be that the self-concept among these adolescents is no more than a mirror reflecting what the student believes others think of him or her. It is congruent with the fact that the highest score was on the subscale for anxiety, taking second place in anxiety among the four ranges. 
The second highest score was in the subscale for academic achievement or feeling with an average of 48.4 points. When analyzing the responses regarding the relationship with their parents, it may be deduced that these youth often manifest the great pressure they receive from their guardians. They feel they cannot let their averages fall, even if they do not feel capable or proficient, perhaps due to various causes such as not comprehending the knowledge, overwhelming fear of being discovered, mistreatment by their parents and teachers who introjected the idea they are less capable or deserving if they do not obtain good grades.

Piers (1984) agrees with this by recognizing that some aspects of the child's self-assessment may represent internalizations of judgments from important others, whether family, friends, or teachers.

The lowest average in this range was in the subscale of popularity with an average of a mere 27.8 points. It may be inferred that expression of affiliative obedience and resignation described by Pérez-Lagunas \& Díaz-Guerrero (1992) (cf. Andrade, 2008), since these categories refer to sacrifice and to care for others before oneself, as well as to following traditional norms set by the culture and in the social systems.

Probably due to his worldview of dependence on nature and religion, luck, and physical beauty, these adolescents use their intelligence to its fullest in the academic field because, even if they could succeed, religious, political, economic, and even natural circumstances may change everything. Thus it is useless striving for something beyond one's control, such as studying in junior high school.

Graphic 3: Subscales in the third range

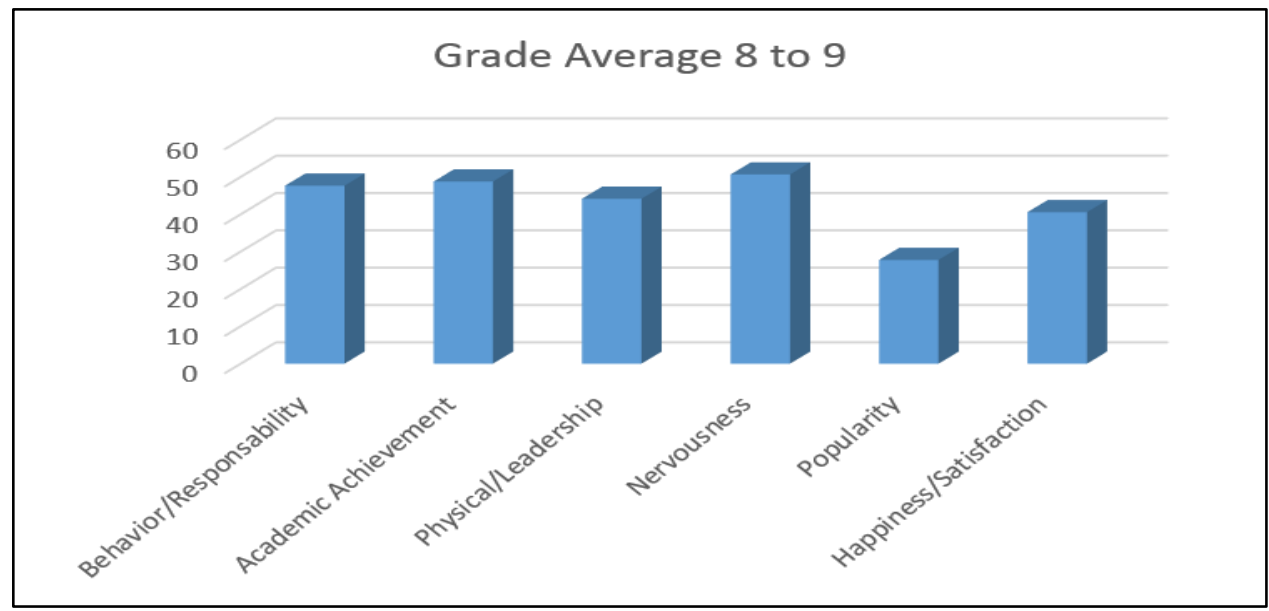

\section{Fourth Range}

The fourth range of scores was a set of 27 questionnaires with low scores in the self-concept scale (225-215 total points) and low grade averages in the third grading period and primary school (averages of 6 to 7 ). The highest score in these was on the subscale of anxiety with an average of 45.6. They may be naïve youth, non-autonomous regarding the opinions of others. Rogers (1981) held that children acquire an external locus of appreciation in the search for love from others, endorsing the value judgments of others and taking them as their own.

The second highest score was found in the second subscale of academic achievement and feelings toward the school. In coping with daily or academic problems, the majority of adolescents with low academic achievement and low self-concept scores do not desire or do not believe there is much they can do to resolve an academic conflict, as if the problem were beyond their control. 
Adolescents with low academic performance and low self-concept scores characterize themselves with adjectives such as introverted, with features of authoritarianism, more lazy, frustrated, and sad. This set of traits poses a problem linked to their temperament and personality.

Perhaps due to their low self-esteem, beyond introversion or their antisocial behavior, these adolescents are considered outmoded, sometimes losers or "misfits." Phillips (1984) names as the illusion of incompetence the fact that otherwise capable children do not have a positive perception of their own abilities.

According to the questionnaire responses, these teens in the fourth range feel more insecure relative their goals, more dependent on everyone to achieve of their expectations, and do not enjoy competitive or team work. This signifies that their vision of the future is very unclear, a very obscure conception of tomorrow and the possibility of setting or meeting possible goals. Most of them think they are very confused about how to succeed.

Of these students have a concept of past and future supported to a great extent by an external locus of control, or a possible external control over their own lives. They have a vision of life where luck and fate, along with the personal characteristics of being likable, sympathetic, and obedient, are more important than effort for personal progress and development.

These students in the fourth range, as may be appreciated, had very low popularity ratings with 29.3 points. Self-esteem is related to behavior and social adjustment insofar as their tendency to approach or avert from the group, to resist initiating social contacts and, with that, provoke rejection behavior in others. This concurs with how adolescents see themselves and how they believe others perceive them.

The lowest score was on the behavior subscale, with an average of only 28.7 points. These students have not developed positive feelings toward the school; they present behavioral problems. In the surveys among students with low academic achievement, a number of similar factors were identified, associated with lower interpersonal trust and related to poor academic achievement. According to the questionnaire, we could say that in most family relationships, these children involve themselves less in resolving everyday or academic problems.

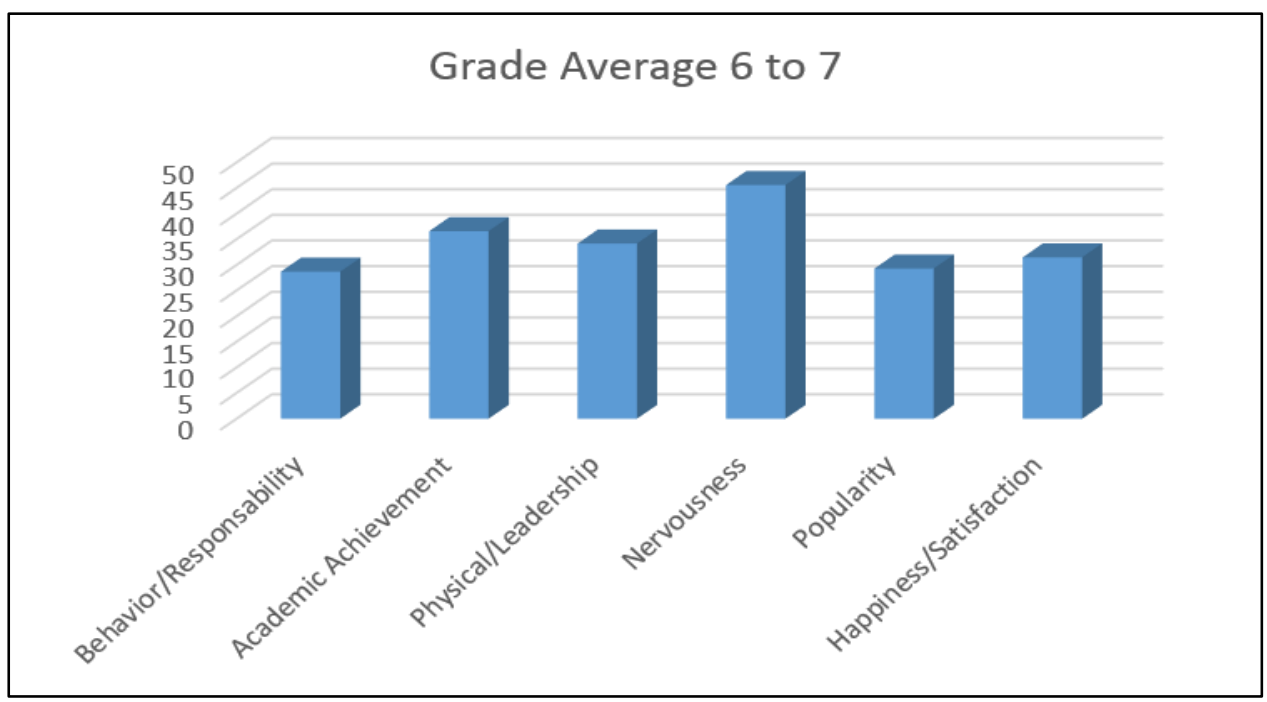

Graphic 4: Subscales in the fourth range 


\section{Conclusion}

The 152 Mexican adolescents in the first range have a positive academic self-concept and high academic achievement, and are characterized by obedience and filiation. They are students who are in the process of becoming autonomous, with a locus of internal control.

The students belonging to the second range of data do not necessarily obtain higher academic achievement, there is a greater positive academic self-concept, nor a lower academic achievement, and there is a low or negative self-concept. The 101 students belonging to the second range consider themselves to be and demonstrate their ability to learn, even when they did not have a high grade average (result, achievement, or good grades) they could obtain it if they set themselves to it. However they are not interested in this because they do not perceive it to be useful for their future work life, entertaining or enjoyable.

In the third range, with 20 students, the generally passive character (which is also generated by school overpopulation) and dependent personality of Mexican adolescents surveyed maintains its grade averages between 7 and 8 due to obedience, status, fear, and membership in a school, social, or family group.

These are passive students with a locus of external control (perhaps due to a state of helplessness that goes back to times of the Spanish Conquest, although the contemporary defenselessness manifests itself in a lack of perception of skills in producing knowledge, also related to a worldview of dependency), so that they may not feel a need for new experiences of autonomous learning outside of their school, religious, family, and, social contexts.

The fourth range had 27 students surveyed with low self-concept and low grades. It is noteworthy that poor academic achievement is perhaps the result not only of the pupils perceiving themselves with the skills necessary for achievement or consider their use beneficial or not, but rather find in the family, social, and school contexts the cause or motivation to "deploy" such capabilities. In some families and cultures, such as the Mexican, competitiveness is often considered negative.

We may also conclude that possessing minimal documentation to enter the working world, difficult economic situation, abuse (since the Spanish Conquest), and corruption have modified negatively the perception of academic achievement and academic self-concept, because learning in and of itself is not very useful, ("Why know academically if foreigners are the ones who know, those that are worthy in the production-research of new technologies?"). In addition to being beyond the control of some other adolescents who need the presence of authority to learn or to work (also dating from the Spanish Conquest), where high or minimally passing marks and not learning are perhaps of greater value. In large classroom groups of 50 students, they must be seated and quiet in order to have vision-control over all the students and be able to hear somebody or give them instructions.

\section{References}

[1] Autoconcepto y rendimiento escolar. In C. Rogers y P. Kutnick (Comps.): Psicología social de la escuela primaria. Madrid: MEC-Paidós, 83-106.

[2] Bandura, A. (1987) Pensamiento y acción. Buenos Aires: Paidós.

[3] Bandura, A. (1982). Self-efficacy mechanism in human agency. American Psychologist, 37, 122-147.

[4] Bandura, A. (1977). Self-efficacy: Toward a unifying theory of behavioral change. Psychology Review, 84, 91215.

[5] Chávez, Ezequiel A. "Ensayo sobre los rasgos distintivos de la sensibilidad como factor del carácter mexicano", Revista Positiva (mim. 3, 1 de marzo de 1901). 
[6] Díaz-Guerrero R. (1994). La psicología del mexicano. Descubrimiento de la etnopsicologia. Mexico City: Trillas. Díaz-Guerrero, R, Pacheco, A. (1994).

[7] Diaz-Loving, R. (2005) Site under construction: An ethnopsychological representation of the Mexican self concept, Revista Interamericana de Psicología, 39 (2), 247-252.

[8] Diaz-Loving, R. (1999) The indigeniosation of psychology: birth of a new science or rekindling of an old one?, Applied Psyhcology: An International Review, 48 (4), 433-449.

[9] Diaz-Loving, R. (1998) Contributions of Mexican ethnopsychology to the resolution of the ethicemic dilemma in personality, Journal of Cross-Cultural Psychology, 29 (1), 104-118.

[10] James, W. 1890. Principles of Psychology. New York: Holt.

[11] Piers, E. (1984) The Piers Harris Children's Self-Concept Scale (The way I feel about myself) Revised Manual,

[12] Rotter, J. (1966). Generalized expectancies for internal versus external control reinforcement. Psychological monographs. 80 (1, n 609)

[13] Santos M. "Objetivar el conocimiento" Revista Mexicana de Psicología, vol. 27, núm. 1, enero, 2010, pp. 103110, Sociedad Mexicana de Psicología A.C. México

[14] Consultado en: http://www.redalyc.org/articulo.oa?id=243016325011 el 15 de abril del 2017.

[15] Valdez-Medina, J.L., González-Arratia, L. \& Reusche, R.M. (2001) El autoconcepto en niños mexicanos y peruanos, Revista Latinoamericana de Psicología, 33 (2), 199-205.

[16] Valdez Medina, J.L. \& López Fuentes, Norma (1996). El autoconcepto en chiapanecos. La psicología social en México, VI, 64-71.

[17] Valdez-Medina, J.L., Mondragón, J.A. \& Morelato, G.S. (2005) El autoconcepto en niños mexicanos y argentinos, Revista Interamericana de Psicología, 39 (2), and Revista de psicología social y personalidad. 10, 1, 1-6.

[18] Valdez Medina, J.L., \& González, N.I. "El autoconcepto en niños mexicanos y peruanos" Revista Latinoamericana de Psicologia year/volume 33 number 002. Bogotá: Fundación Universitaria Konrad Lorenz. pp. 195-205. 